\title{
COMMENT
}

\section{THE WORK OF THE DELAWARE FIDUCIARY COMMISSION}

Gilbert T. STEPHENSON*

$\mathrm{O}$ N APRIL 22, I93I, the Senate and House of Representatives of the State of Delaware, by joint resolution, authorized and directed the Governor of the State to appoint a commission of nine members to make a thorough study of the laws of the State with respect to the descent and distribution of property and to the settlement of estates and the administration of trusts, "with a view," states the resolution, "to the modernization, simplification, and codification of such laws."

The commission, in turn, was directed by the resolution:

"to investigate and to recommend as to the advisability of a revision of the laws of the State of Delaware affecting the descent and distribution of property of intestates, the duties and powers of executors, administrators, guardians, trustees, and other fiduciaries, and all other statutes of this State as the commission may deem advisable for the purpose of modernizing and simplifying the law relating to estates and trusts and the systems for the devolution of real and personal property, and to prepare proposed legislation for such purposes."

The members of the commission were to serve without compensation but were to be reimbursed for their actual expenses, and the legislature appropriated two thousand dollars for expenses.

The purpose of this article is not to discuss what the commission accomplished in the way of new legislation but rather to discuss how it went about its work.

The need for such a commission arose from the fact that the laws with respect to estates, trusts, devolution of property, and the like had been passed piecemeal, one act at a time, by succeeding sessions of the General Assembly. For instance, one session undertook to modernize the laws of descent of real property; another, the laws of distribution of personal property. One session had enacted a statute with respect to the effect of the birth of a first child upon a parent's will; another session, a statute upon the effect of the birth of a second or a later child upon a parent's will.

* Vice President, Equitable Trust Co., Wilmington, Del.

37 Del. Laws (193r), 901-2, c. 308. 
Naturally gaps and laps in the laws resulted which gave rise to the need for the consideration of these laws as a whole and for the coordination of the body of the statutory law of the State on cstates, trusts, and other fiduciary subjects.

In the appointment of the commission of nine, the Governor drew upon the groups of citizens who were most interested in and concerned with the laws of estates and trusts. He appointed two active trust men, one officer of a probate court, four lawyers in active practice who were also attorneys for trust companies, and two business men. Thus the trust institutions, the probate courts, the bar, and the general public were represented on the commission.

The commission, which was appointed by the Governor in July following the adjournment of the legislature, held its organization mecting the following October and elected a chairman, vice chairman, and secretary. As a preliminary step to the work of the commission each member was furnished an indexed, arranged, annotated compilation of the existing laws of the State relating to trusts and estates. This compilation, which comprised a typed volume of over three hundred pages, while mechanically the most tedious phase of the work, proved to be an essential one in that it brought together from the code and from the session laws the statutes relating to the same subject and showed the gaps and the laps and, in a few cases, the inconsistencies.

In December, I93I, the secretary of the commission addressed a letter to each of the active members of the bar of Delaware inviting him to make suggestions of subjects to be considered and of changes in the laws of the State relating to matters to be taken up by the cornmission. From this and from other sources the commission received twenty-nine different subjects for consideration. The twenty-nine subjects suggested for consideration were arranged so that kindred subjects-such, for instance, as dower, curtesy, and intestate distribution-might be treated together, and each group of kindred subjects was assigned to a subcommittee of the commission.

The subcommittees were then given ample time-several months in some cases-to study the subjects assigned to them. Following that, the full commission met in a series of meetings and took up, one after another, the reports of the subcommittees dealing at first with the substance only and later with the form of the legislation. In a large number of cases the subcommittee found, as it went deeper and deeper into a subject, that it was not, in its opinion, a proper subject for legislation or that it was not a proper subject for consideration by this commission. Thus, as the sub- 
committees and the commission went ahead with their work the number of subjects for legislation was reduced.

After the substance of the new legislation had been agreed upon by the commission, a new subcommittee was named to draft the bills covering the proposed legislation. This committee was, of course, composed of the members of the commission who had had experience in drafting statutes.

By or before the convening of the 1933 session of the General Assembly the commission had its report completed. This report, covering forty-odd pages, contained a narrative account of the work of the commission, an explanation in untechnical language of the proposed legislation and the reasons therefor, and the actual drafts of bills covering the proposed legislation. A copy of this report was presented to the Governor and a copy each to the Senate and House of Representatives at the I933 session. On the same day that the report was formally presented to the Senate and House of Representatives the bills were introduced.

Having made its report containing the recommended legislation and having seen that the bills covering the recommended legislation were introduced, the commission made no effort to push the legislation through the General Assembly. That is to say, it did not lobby for its bills. It felt that its functions were to make research, to suggest legislation, and to draft bills covering such legislation and that it would be presumptuous for it to go further in advocating the legislation it recommended. The General Assembly, however, realizing that the bills had been well considered over a considerable period of time by a regularly constituted commission, accepted the recommendations in the spirit in which they were offered and proceeded to pass all but two of the bills. As to these two bills-one relating to the descent and distribution of the property of intestates and the other to the kindred subjects of dower and curtesy-after the bills had been drafted the commission felt that some features had not been duly considered and preferred that the passage of the bills be postponed.

The bills that were passed covered the following subjects: The revocation of wills by birth and marriage, caveats to and reviews of wills, service of process on non-resident executors and administrators, notices of debts of decedents' estates, transfer of corporate securities by executors and administrators, notices of administration, decrees of distribution, protective trusts, exceptions to fiduciaries' accounts, and widow's allowance.

In Delaware the Fiduciary Commission has proved to be an admirable instrumentality for the modernization, simplification, and codification of the laws with respect to estates, trusts, and kindred subjects. The appointment of the commission by the Governor of the State, under author- 
ity and direction of the General Assembly itself, at once gave the commission a standing with the General Assembly. The selection of the members of the commission from the bar, the probate courts, the trust institutions, and the general public made it a general and not a special-interest group. By asking all the active members of the bar to submit subjects for consideration, the commission had the benefit of a wide variety of suggestions from many angles. Above all, by taking plenty of time during the legislative off-year, the commission was able to do its work deliberately and unhurriedly and to give to each subject the consideration it merited.

While the commission expired by its own limitation with the I933 session of the General Assembly, the Governor requested the former members of the commission to consider and recommend to the r935 session any other needed legislation affecting estates and trusts and kindred subjects. This enables the commission in a way to carry on and round out its work of modernizing, simplifying, and codifying the law on these subjects.

The method of attacking the problem may not be feasible in just this way in some states. It has worked well in Delaware. It suggests to other states one way of going about the improvement of their fiduciary laws in a systematic and thoroughgoing way.

\section{A PUBLICATION OF THE AMERICAN STATE STATUTE LAW*}

Paul L. Sayre $†$

$7 \mathrm{HE}$ purpose $\mathrm{x}^{\mathrm{x}}$ of this paper is the preliminary and limited one of presenting the several plans for a publication of the American state statute law that have been evolved thus far, with some comment on their advantages and disadvantages and some explanation of the occasion for the undertaking itself and the service which we may reasonably expect it to render. Dean Wigmore and Professor Philbrick have been deeply interested in this matter for many years and have freely given of their time in canvassing the field. In here presenting several plans that have been evolved, and adding one of my own, I do not suggest for a moment

* A paper read before the joint table on Property and Legislation at the annual meeting of the Association of American Law Schools, December 27, 1934.

$\dagger$ Professor of Law, Iowa Law School.

I Professor Bordwell asked me to present "The Project For a Modern and Adequate Stimson," that is to say, a publication of the American statute law. This is an undertaking which he has urged for many years, in and out of season, and in the most courageous and generous spirit. His own monograph, The Statute Law of Wills, may well point the way to the larger work. 